\title{
Peran Relasi Orang Tua-Anak dan Tekanan Teman Sebaya terhadap Kecenderungan Perilaku Pengambilan Risiko
}

\author{
Friska Tri Andayani, dan Endang Ekowarni ${ }^{2}$ \\ ${ }_{1}^{1}$,Fakultas Psikologi Universitas Gadjah Mada
}

\begin{abstract}
Abstrack. This study is based on the increase of risk-taking behaviour among adolescents in Indonesia, both in quantity and variety of behaviour shapes. Central Bureau of Statistic state that the risky behaviour of adolescents aged 15-19 years increased. The aim of this study was to determine whether the parent-child relationships and peer pressure contribute to the risk-taking behaviour tendency among adolescents. The methode used in this study is a quantitative approach and the data collected through surveys. The measuring instruments used in this study are Risk Taking Behaviour Tendency Scale, Parent-child Relationships Scale, and Peer Pressure Scale. Subjects of this research were 218 adolescents who live in Yogyakarta. The instrument was analyzed by content validity and reliability with Cronbach's Alpha $\left(\alpha_{\text {RTBTS }}=0,935 ; \alpha_{\text {PCRS }}=0,923\right.$; $\left.\alpha_{\mathrm{PPS}}=0,901\right)$. Analysis of the data was using multiple regression. The results of the study show that parent-child relationships and peer pressure can jointly contribute to the risk taking behaviour trend $(\mathrm{F}=15.823, \mathrm{p}<0,05)$. The effective contribution of predictor variable to the criterion variable is 13 percents.
\end{abstract}

Keywords: risk taking behaviour, parent-child relationship, peer pressure

Abstrak. Penelitian ini didasari oleh meningkatnya perilaku pengambilan risiko pada remaja di Indonesia, baik dari jumlah maupun variasi bentuk perilakunya. Badan Pusat Statistik menyatakan bahwa perilaku berisiko remaja usia 15-19 tahun semakin meningkat. Penelitian ini bertujuan untuk mengetahui relasi orang tua-anak dan tekanan teman sebaya berperan terhadap kecenderungan perilaku pengambilan risiko pada remaja. Metode yang digunakan adalah pendekatan kuantitatif dan data dikumpulkan melalui survei. Alat ukur yang digunakan dalam penelitian ini adalah Skala Kecenderungan Perilaku Pengambilan Risiko, Skala Relasi Orang Tua-Anak, dan Skala Tekanan Teman Sebaya. Subjek penelitian ini berjumlah 218 remaja yang tinggal di kota Yogyakarta. Instrumen penelitian dianalisis dengan validitas isi dan reliabilitas dengan Cronbach's Alpha ( $\alpha_{\mathrm{KPPR}}=0,935 ; \alpha_{\mathrm{ROA}}=0,923 ; \alpha_{\mathrm{TTS}=0,901)}$. Analisis data menggunakan regresi berganda. Hasil penelitian menemukan bahwa relasi orang tua-anak dan tekanan teman sebaya bersama-sama dapat berperan terhadap kecenderungan perilaku pengambilan risiko $(F=15,823 ; p<0,05)$. Sumbangan efektif variabel prediktor terhadap variabel kriterium sebesar 13 persen.

Kata kunci: perilaku pengambilan risiko, relasi orang tua-anak, tekanan teman sebaya

\footnotetext{
${ }^{1}$ Korespondensi mengenai isi artikel ini dapat disampaikan melalui andayani.friska@gmail.com

2 Atau melalui ekowarni@ugm.ac.id

E-JURNAL GAMA JOP
} 
Perilaku pengambilan risiko di kalangan remaja dari tahun ke tahun semakin meningkat, baik dari jumlahnya maupun variasi bentuk perilaku pengambilan risiko yang dimunculkan. Perilaku berisiko yang biasanya dilakukan adalah berupa perilaku yang memberikan dampak negatif, seperti perilaku mengemudi dengan sembrono (kebut-kebutan di jalan raya, melanggar lalu lintas, tidak menggunakan helm saat berkendara), penggunaan alkohol, merokok, seks bebas, kehamilan, dan perkelahian (Karriker-Jaffe, Foshee, Ennett, \& Suchindran, 2008). Perilaku-perilaku tersebut berpotensi merugikan dan merusak diri remaja, bahkan dapat menimbulkan kematian (Eaton, Kann, \& Kinchen, 2006). Selain itu, perilaku pengambilan risiko juga berdampak bagi kesehatan dan kesejahteraan remaja (Ritcher, 2010).

Meskipun demikian, tidak semua jenis perilaku pengambilan risiko yang dilakukan oleh remaja mengarah pada perilaku negatif. Menurut Skaar (2009) perilaku pengambilan risiko berpotensi menghasilkan efek yang positif maupun negatif. Perilaku ini tergantung dengan konsekuensi yang didapatkan dari perilakunya, jika individu tersebut merasa lebih banyak mendapat manfaat yang positif, mereka akan melakukannya walaupun rentan dengan risiko. Contoh perilaku yang positif adalah mengikuti kegiatan pemilihan ketua OSIS (Organisasi Intera Sekolah), mengikuti kegiatan pecinta alam, menjadi sukarelawan pada korban bencana alam, mengikuti olahraga ekstrem, dan juga kegiatan sukarela (misal, donor darah) yang dilakukan oleh remaja.

Namun pada penelitian ini peneliti fokus kepada perilaku pengambilan risiko negatif yang biasanya dilakukan remaja. Hal ini mengacu pada data mengenai perilaku berisiko yang dilakukan oleh remaja di Indonesia. Menurut Informasi Kementerian Pemuda dan Olahraga pada 139 tahun 2009, berdasarkan laporan dari Mabes Polri tahun 2008 menunjukkan hasil yang cukup memprihatinkan. Pelanggaran lalu lintas profesi mahasiswa/pelajar menduduki peringkat ke tiga dengan jumlah pelanggaran sebesar 557.507 kejadian di bawah urutan profesi lain-lain dan pengemudi sebesar 2.260.193 dan 621.394 kejadian. Setelah itu disusul dengan anggota PNS dan anggota TNI/Polri di peringkat terakhir. Selain itu, juga terdapat data pelaku kecelakaan lalu lintas (Laka Lantas) berdasarkan laporan dari Mabes Polri tahun 2008 (Informasi Kementerian Pemuda dan Olahraga, 2009) memperlihatkan angka yang cukup tinggi, yaitu pelaku Laka Lantas profesi mahasiswa/pelajar menduduki peringkat ke dua dengan jumlah pelaku sebesar 12.298 (17.62\%) kejadian di bawah urutan profesi lain-lain sebesar 37.764 (54.11\%) kejadian.

Perilaku remaja yang berisiko selain melanggar lalu lintas, yaitu kekerasan, penggunaan alkohol, dan penyalahgunaan obat-obatan. Perilaku tersebut telah menjadi topik pemberitaan di media. Bahkan di Amerika Serikat menurut Topolski (Leather, 2009) penggunaan dan penyalahgunaan alkohol, narkoba, dan perilaku seksual berkontribusi pada masalah sosial, morbiditas, dan mortalitas pada remaja. Begitu juga di Indonesia, menurut Badan Pusat Statistik tahun (BPS, 2012), melalui survei kesehatan reproduksi remaja dengan sampel sebanyak 8.902 wanita dan 10.980 pria yang berusia 15-24 tahun dan belum menikah. Ditemukan bahwa perilaku merokok, minum-minuman beralkohol, dan penggunaan obat terlarang yang ada di Indonesia menunjukkan hasil yang cukup tinggi (Survei Demografi dan Kesehatan Indonesia Tahun 2012, 2013). Data merokok pada wanita ditemukan sebanyak 8,9 persen dan 3,5 persen meminum alkohol. Untuk pria, didapatkan 74,4 persen merokok dan 30,2 persen meminum alkohol, sedangkan penggunaan 
obat-obatan terlarang jauh lebih terbatas, yaitu kurang dari 1 persen untuk wanita dan 2,8 persen untuk pria. Berdasarkan data di atas, dapat disimpulkan bahwa pria lebih berisiko dibandingkan wanita.

Selain data merokok, meningkatnya jumlah kehamilan pada usia remaja di Indonesia yang diperoleh dari Badan Kependudukan dan Keluarga Berencana $(\mathrm{BKKBN})$, menemukan tingginya usia kehamilan pada remaja Indonesia saat ini. Menurut survei terakhir dari Badan Pusat Statistik (BPS) melalui Survei Demografi dan Kesehatan Indonesia (SDKI), tahun 2012 angka kehamilan remaja pada kelompok usia 15-19 tahun mencapai 48 dari 1.000 kehamilan. Dari angka ini membuktikan bahwa pernikahan dini dan seks pranikah di kalangan remaja semakin tinggi (Kesehatan Reproduksi Remaja, 2013).

Berdasarkan data-data yang dipaparkan di atas, dapat disimpulkan bahwa pengambilan perilaku berisiko, khususnya pada remaja di Indonesia meningkat secara signifikan dari tahun ke tahun. Kondisi ini menggambarkan bahwa perlu dilakukan upaya untuk mengurangi permasalahan tersebut, khususnya di kotakota besar di Indonesia. Menurut Badan Pusat Statistik (2012), tempat tinggal di perkotaan memiliki jumlah perokok, pengguna alkohol dan obat-obatan lebih tinggi dibanding perdesaan.

Kota Yogyakarta merupakan salah satu kota terbesar di Indonesia, dikenal dengan kota pelajar, budaya, dan pariwisata. Dikatakan sebagai kota pelajar, karena hampir $20 \%$ penduduk produktifnya adalah pelajar dan terdapat 137 perguruan tinggi. Kota ini diwarnai dinamika pelajar dan mahasiswa yang berasal dari berbagai daerah di Indonesia (Kementerian Dalam Negeri [Kemendagri], 2014). Semakin tinggi jumlah remaja di daerah perkotaan, maka semakin tinggi permasalahan yang akan dihadapi remaja.
Hal tersebut dibuktikan dengan pemberitaan mengenai perilaku remaja masih menjadi berita utama di media, seperti koran atau elektronik.

Kecelakaan dan pelanggaran lalu lintas adalah salah satu permasalahan yang dilakukan oleh remaja di kota Yogyakarta. Mengemudikan kendaraan dengan kecepatan di atas rata-rata, melanggar lalu lintas, dan tidak mengenakan pengaman saat berkendara adalah penyebabnya. Berdasarkan data BPS D.I. Yogyakarta (2015) ditemukan jumlah pelaku kecelakaan lalu lintas mencapai 2.968 orang, dan 1.494 orang pelakunya adalah usia 10-30 tahun. Begitu juga jumlah kecelakaan dari tahun ke tahun juga semakin meningkat, dari 662.753 kecelakaan pada tahun 2003, menjadi 3.068.590 kecelakaan lalu lintas. Kota Yogyakarta berada diurutan kedua yang sering terjadi pelanggaran lalu lintas setelah Sleman, dengan selisih 1.291 pelanggaran lalu lintas.

Perilaku seksual remaja di D.I. Yogyakarta menurut survei BKKBN (2011) menemukan $71.1 \%$ pernah pacaran, $56.8 \%$ pertama kali punya pacar pada usia 15-17 tahun. Saat pacaran mengungkapkan kasih sayang $95.4 \%$ berpegangan tangan, 35.6\% cium bibir, 9.5\% meraba/merangsang. Dari semua remaja di daerah DIY yang pacaran sebanyak $3.4 \%$ pernah berhubungan seksual di luar nikah dan ada 2.5\% tergantung situasi dan kondisi. Perilaku seksual yang dilakukan oleh remaja berpotensi terhadap pernikahan dini dan memberikan dampak negatif pada masa depan remaja. Akibat dari perilaku seksual, pernikahan dini atau bawah umur (usia pria $<19$ tahun, wanita $<16$ tahun) di Kabupaten Sleman, Bantul, dan Kota Yogyakarta terus mengalami peningkatan dalam kurun 10 tahun terakhir. Di Kabupaten Sleman rata-rata pernikahan di bawah umur per tahun adalah 533 perkawinan, sedangkan di Kabupaten Bantul, rata-rata pernikahan dini mencapai 
90-120 pasangan. Sebagian besar pernikahan itu adalah akibat dari hamil diluar nikah dan menikah antar sesama teman sekolah atau seumuran (Faska, 2015).

Perilaku berisiko yang lain juga dilakukan oleh remaja di DIY, yaitu tindak kejahatan. Melalui Badan Pusat Statistik Provinsi D.I. Yogyakarta (2012) diperoleh data mengenai pelaku tindak kejahatan, tercatat 7,19\% pelaku kejahatan dilakukan oleh anak-anak (usia $<16$ tahun), sementara 10 anak $(5,49 \%)$ diantaranya berjenis kelamin perempuan. Sebanyak 44,58\% pelaku tindak kejahatan anak-anak pada tahun 2011 adalah berasal dari Kabupaten Sleman, Kota Yogyakarta 34,72\%, Kabupaten Bantul 10,88\%, Kabupaten Kulonprogo 3,63\%, dan Kabupaten Gunungkidul 6,22\%.

Perilaku pengambilan risiko pada remaja terjadi karena banyak faktor yang menyebabkan, berperan, atau memperbesar peluang munculnya, seperti faktor biologis, psikologis, dan lingkungan (Bonino, Cattelino, \& Clairano, 2005). Faktor lingkungan memandang perilaku pengambilan risiko berasal dari keluarga dan teman sebaya (Sofronoff, Dalgliesh, \& Kosky, 2004). Remaja yang mendapatkan dukungan dari orang tuanya, mereka memiliki kemungkinan yang lebih kecil untuk terlibat dalam perilaku pengambilan risiko. Penelitian Garnefski \& Diekstra (Sofronoff, et al. 2004) menemukan bahwa remaja dengan gangguan emosional dan perilaku bermasalah disebabkan oleh kurangnya perhatian dan dukungan dari keluarga, terlebih jika remaja kurang mendapatkan dukungan dari satu sistem, seperti keluarga, sekolah, atau teman-teman (Klahr, McGue, \& Burt, 2011) lebih mungkin untuk melakukan perilaku berisiko dan perilaku anti sosial (Burt, McGue, Lacono, \& Krueger, 2006).

Konsisten dengan penelitian di atas, bahwa emosional positif, dorongan, serta semangat dari keluarga dapat menjadi pelindung terhadap perilaku pengambilan risiko pada remaja. Dalam penelitian longitudinal terhadap keluarga dampaknya pada perilaku pengambilan risiko remaja, Fisher \& Feldman (dalam Sofronoff, et al. 2004) menemukan bahwa remaja cenderung mudah terlibat dalam kegiatan berisiko, jika mereka datang dari keluarga yang memiliki sedikit keterampilan dalam pemecahan masalah. Remaja tersebut akan mudah dipengaruhi oleh teman-teman dan orang dewasa lainnya daripada keluarga mereka. Penelitian oleh Qu, Fuligni, Galvan, dan Telzer (2015) menemukan bahwa hubungan dengan keluarga berpengaruh terhadap perubahan reaktivitas saraf pada bagian pengambilan keputusan berisiko. Kesimpulannya, relasi orang tua-anak penting untuk mencegah perilaku pengambilan risiko dan relasi yang positif antara orang tua-anak berhubungan dengan prestasi yang lebih baik di sekolah (Turley, Desmond, dan Bruch, 2010).

Faktor lingkungan yang berpengaruh terhadap perilaku pengambilan risiko selain keluarga adalah teman sebaya. Menurut Jessor dan Jessor (Sales \& Irwin, 2009) pengaruh rekan-rekan relatif lebih besar dibandingkan dengan orang tua bila dikaitkan dengan kecenderungan remaja terhadap perilaku bermasalah. Selain itu, Jessor juga menemukan bahwa teman sebaya memberikan pengaruh lebih besar dalam menggunakan ganja, minumminuman, pelanggaran lalu lintas, dan perilaku seksual sebelum waktunya. Hal ini membuktikan bahwa teman sebaya memberikan kontribusi bagi remaja terhadap perilaku pengambilan risiko. Penelitian tersebut didukung oleh beberapa ahli bahwa teman sebaya berkontribusi terhadap aksi kebut-kebutan di jalanan (Gheorghiu, Delhomme, \& Felonneau, 2015), penggunaan alkohol (Peacock \& Bruno, 2015), berpengaruh terhadap penyesuaian sosial remaja (Oni, 2010), dan 
aktivitas seksual (Crockett, Raffaelli, \& Shen, 2006).

Berbagai hal sudah dilakukan oleh pemerintah, khususnya pemerintah Yogyakarta dalam menangani dan mengurangi tindakan remaja yang dapat menimbulkan masalah. Salah satu kegiatan tersebut adalah Youth Forum DIY yang difasilitasi oleh PKBI (Perkumpulan Keluarga Berencana Indonesia). Youth Forum adalah sebuah komunitas tempat berkumpulnya remaja untuk menyuarakan hak-haknya dan wadah bagi remaja-remaja yang mengedukasi mengenai isu-isu dan perilaku seksual. Selain itu, forum ini juga berfungsi sebagai tempat konseling bagi remaja-remaja yang bermasalah dan menghimbau para remaja Yogyakarta untuk tidak melakukan berbagai perilaku yang merugikan diri sendiri dan orang lain. Adapun kegiatan yang sudah dilakukan Youth Forum adalah healing, sosialisasi, Youth Camp, siaran radio dan TV, public hearing, audiensi, aksi-aksi di event remaja, pengawalan kasus, pembuatan majalah, pertemuan rutin, bedah buku, turun lapangan ke SMA-SMA di Jogja, dan pembuatan film yang berkaitan dengan isuisu remaja (Savitri, 2015).

Namun, pada kenyataannya perilakuperilaku bermasalah dan isu-isu negatif mengenai remaja tidak kunjung menurun. Ada berbagai hal yang tidak tergali yang dapat berperan sebagai pemicu dalam remaja mengambil risiko. Sebagaimana kasus yang telah dipaparkan, seperti perilaku melanggar lalu lintas, penyalahgunaan narkoba, merokok, meminum alkohol, seks bebas, yang dilakukan oleh remaja, khususnya remaja kota Yogyakarta menunjukkan bahwa isuisu remaja serta program pemerintah belum tampak efektif untuk mengurangi perilaku berisiko remaja. Data masih menunjukkan angka yang cukup tinggi pada remaja sebagai pelaku perilaku bermasalah.
Berdasarkan permasalahan, kajian literatur serta penelitian sebelumnya, maka penelitian ini menguji hipotesis yaitu, relasi orang tua-anak dan tekanan teman sebaya secara bersam-sama berperan terhadap kecenderungan perilaku pengambilan risiko. Tujuan dari penelitian ini adalah menguji signifikansi variabel-variabel prediktor (relasi orang tua-anak dan tekanan sebaya) terhadap variabel kriterium (kecenderungan perilaku pengambilan risiko) dan menemukan kontribusi efektif masing-masing variabel.

\section{Metode}

\section{Subjek penelitian}

Total subjek yang berpartisipasi dalam penelitian ini sebanyak 218 remaja laki-laki yang tinggal di Kota Yogyakarta. kriteria inklusif terdiri dari: (a) Remaja laki-laki yang berusia 15 sampai 18 tahun; ; (b) masih mempunyai orang tua kandung (ayah dan ibu); dan (c) tinggal bersama orang tua kandung. Total subjek yang berpartisipasi dalam uji coba skala sebanyak 78 remaja. Total subjek yang berpartisipasi dalam penelitian sebanyak 218 remaja. Deskripsi subjek terdiri dari $12 \%$ berusia 15 tahun, 33\% berusia 16 tahun, $37 \%$ berusia 17 tahun, dan $18 \%$ berusia 18 tahun.

\section{Desain penelitian}

Penelitian ini menggunakan pendekatan kuantitatif dengan desain survei lapangan. Survei lapangan biasanya digunakan untuk mengevaluasi sikap atau perilaku tertentu, serta memprediksi perilaku (Alsa, 2014).

\section{Instrumen pengukuran}

Penelitian ini menggunakan tiga instrumen yang dikembangkan oleh penulis dan dimodifikasi dari penelitian sebelumnya. Deskripsi instrumen pengukuran yang digunakan dalam penelitian ini adalah pertama, skala Kecenderungan Perilaku Pengambilan Risiko yang penulis 
berdasarkan konsep mengenai perilaku pengambilan risiko yang dikembangkan oleh Gullone dan Moore (2000). Skala ini bertujuan untuk mengukur kecenderungan skala Peer Pressure Inventory (PPI) milik Clasen \& Brown (1987). Skala ini menggunakan model deferensial semantik dengan format 7 pilihan jawaban. Akan

Tabel 1.

Rerata Hipotetik dan Rerata Empiris

\begin{tabular}{lrrrrrrrrr}
\hline \multirow{2}{*}{ Variabel } & \multicolumn{4}{c}{ Rerata Hipotetik } & \multicolumn{5}{c}{ Rerata Empirik } \\
\cline { 2 - 11 } & Max & Min & $\boldsymbol{\mu}$ & $\boldsymbol{\sigma}$ & Max & Min & $\overline{\boldsymbol{x}}$ & $\boldsymbol{\sigma}$ \\
\hline $\begin{array}{l}\text { Kecenderungan Perilaku } \\
\text { Pengambilan Risiko }\end{array}$ & 165 & 33 & 99 & 22 & 141 & 31 & 62,4 & 20,4 \\
\hline Relasi Orang Tua-Anak & 170 & 34 & 102 & 22,6 & 164 & 33 & 121,2 & 16,6 \\
\hline Tekanan Teman Sebaya & 114 & 0 & 57 & 19 & 96 & 18 & 55,4 & 18,9 \\
\hline
\end{tabular}

Keterangan: Max = skor maksimum; Min = skor minimum; $\mu=$ rerata hipotetik;

$\bar{x}=$ rerata empirik; $\sigma=$ standar deviasi

perilaku pengambilan risiko pada remaja. Skala Kecenderungan Perilaku Pengambilan Risiko terdiri dari dua aspek perilaku ceroboh (reckless behaviour) dan perilaku memberontak (rebellious behaviour). Skala ini terdiri dari 35 aitem dan menggunakan model Likert dengan format lima pilihan jawaban yaitu "Sangat Sesuai", "Sesuai", "Netral", "Tidak Sesuai", dan "Sangat Tidak Sesuai" terhadap aitem yang berbentuk pernyataan. Jumlah aitem yang digunakan dalam penelitian adalah 33 aitem $(\alpha=0,935)$. Kedua, Skala Relasi Orang Tua-Anak yang dikembangkan oleh penulis berdasarkan konsep mengenai relasi orang tua-anak yang dikembangkan oleh Dixson, Bermes, \& Fair (2014) dan Jahun Kim (2011). Skala Relasi Orang Tua-Anak mengukur dua aspek yaitu keharmonisan keluarga dan penyelesaian konflik. Skala ini terdiri dari 39 aitem dan menggunakan model Likert dengan menggunakan format lima pilihan jawaban yaitu "sangat setuju", "setuju", "netral", "tidak setuju", dan "sangat tidak setuju" terhadap aitem-aitem yang berbentuk pernyataan. Jumlah aitem yang digunakan dalam penelitian ini adalah 35 aitem $(\alpha=0,923)$. Ketiga, Skala Tekanan Teman Sebaya (Peer Presure Inventory) yang dirancang untk mengukur penilaian remaja terhadap tekanan yang diperoleh dari teman sebayanya. Skala ini merupakan tetapi, dengan pertimbangan kemudahan subjek penelitian dalam memilih, maka penulis memodifikasi format jawaban menjadi model Likert dengan 4 pilihan jawaban terhadap aitem yang berbentuk pernyataan, yang terdiri dari "Sangat Banyak Tekanan", "Banyak Tekanan", "Sedikit Tekanan", dan "Tidak Ada Tekanan". Jumlah aitem yang digunakan dalam penelitian ini adalah 38 aitem $(\alpha=$ 0,901).

\section{Analisis data}

Data dianalisis dengan analisis regresi ganda dengan perangkat lunak statistik. Uji asumsi yang digunakan dalam penelitian ini adalah normalitas, linearitas, dan multikolinearitas.

\section{Hasil}

Deskripsi subjek penelitian

Subjek penelitian adalah remaja laki-laki berusia 15-18 tahun yang tinggal di Kota Yogyakarta dan masih mempunyai orang tua kandung serta tinggal bersama dengan orang tua tersebut. Total subjek penelitian sebanyak 218 orang. Subjek diperoleh dari beberapa SMA dan SMK di Kota Yogyakarta.

Rata-rata hipotetik dan empirik

E-JURNAL GAMA JOP 
Deskripsi data disajikan dalam rerata hipotesis dan rerata empirik yang diperoleh dari respon jawaban sujek terhadap setiap skala yang diberikan. Deskripsi data penelitian dapat dilihat pada Tabel 1 .

Berdasarkan analisis deskriptif empirik untuk data kecenderungan perilaku pengambilan risiko didapatkan skor maksimum 141 dan skor minimum sebesar 31. Berdasarkan skor retata menunjukkan bahwa rerata empirik $(\bar{x}=62,4)$ lebih rendah dibandingkan rerata empirik $(\sigma=16,6)$ lebih rendah daripada standar deviasi hipotetik $(\sigma=22,6)$. Hal tersebut menunjukkan bahwa relasi orang tua-anak subjek penelitian memiliki variasi yang rendah.

Berdasarkan analisis deskriptif empirik untuk data tekanan teman sebaya didapatkan skor maksimal sebesar 96 dan skor minimal sebesar 18. Berdasarkan skor rerata menunjukkan bahwa rerata empirik $(\bar{x}=55,4)$ lebih rendah dari rerata hipotetik $(\mu=57)$ yang menunjukkan bahwa tekanan

Tabel 2.

\begin{tabular}{|c|c|c|c|c|c|}
\hline Variabel & Kategorisasi & Rumus Distribusi & Distribusi & $\mathbf{N}$ & $\%$ \\
\hline \multirow{3}{*}{$\begin{array}{l}\text { Kecenderungan perilaku } \\
\text { pengambilan risiko }\end{array}$} & Rendah & $X<(\mu-1 . \sigma)$ & $X<77$ & 164 & 75 \\
\hline & Sedang & $(\mu-1 . \sigma) \leq X<(\mu+1 . \sigma)$ & $77 \leq X<154$ & 54 & 25 \\
\hline & Tinggi & $X \geq(\mu+1 . \sigma)$ & $X \geq 154$ & 0 & 0 \\
\hline \multirow[t]{3}{*}{ Relasi orang tua-anak } & Rendah & $X<(\mu-1 . \sigma)$ & $X<79,4$ & 3 & 1,4 \\
\hline & Sedang & $(\mu-1 . \sigma) \leq \mathrm{X}<(\mu+1 . \sigma)$ & $79,4 \leq X<158,8$ & 214 & 98,1 \\
\hline & Tinggi & $X \geq(\mu+1 . \sigma)$ & $X \geq 158,8$ & 1 & 0,5 \\
\hline \multirow[t]{3}{*}{ Tekanan teman sebaya } & Rendah & $X<(\mu-1 . \sigma)$ & $X<38$ & 40 & 18,4 \\
\hline & Sedang & $(\mu-1 . \sigma) \leq X<(\mu+1 . \sigma)$ & $38 \leq X<76$ & 136 & 62,3 \\
\hline & Tinggi & $X \geq(\mu+1 . \sigma)$ & $x \geq 76$ & 42 & 19,3 \\
\hline
\end{tabular}

hipotetik ( $\sigma=99)$ yang menunjukkan bahwa kecenderungan perilaku pengambilan risiko subjek penelitian cukup rendah. Hasil perbandingan standar deviasi menunjukkan bahwa standar deviasi empirik $(\sigma=20,4)$ lebih rendah daripada standar deviasi hipotetik $(\sigma=22)$. Hal ini menunjukkan bahwa kecenderungan perilaku pengambilan risiko subjek memiliki variasi yang lebih rendah, dengan kata lain kecenderungan perilaku pengambilan risiko antara subjek satu dan lainnya memiliki kemiripan atau seragam.

Berdasarkan analisis deskriptif empirik untuk data relasi orang tua-anak didapatkan skor maksimal sebesar 164 dan skor minimal sebesar 33. Berdasarkan skor rerata menunjukkan bahwa skor rerata empirik $(\bar{x}=121,2)$ lebih tinggi daripada skor rerata hipotetik $(\mu=102)$ yang menunjukkan bahwa relasi orang tua-anak subjek penelitian positif. Hasil perbandingan standar deviasi menunjukkan bahwa standar deviasi teman sebaya dari subjek penelitian rendah. Hasil perbandingan standar deviasi empirik $(\sigma=18,9)$ lebih rendah daripada standar deviasi hipotetik $(\sigma=19)$. Hal ini menunjukkan bahwa tekanan teman sebaya subjek penelitian memiliki variasi yang rendah.

\section{Kategorisasi skor data}

Kategorisasi data dilakukan bertujuan untuk mengetahui persentse skor yang didapatkan dari dari subjek penelitian.

Berdasarkan tabel 2., sebagian besar kecenderungan perilaku pengambilan risiko subjek penelitian berada dalam kategori rendah (75\%). Sebanyak 25\% kecenderungan perilaku pengambilan risiko subjek penelitian berada pada kategori sedang, dan $0 \%$ subjek penelitian berada pada kategori tinggi. Pada variabel relasi orang tua-anak, Sebagian besar relasi orang tua-anak subjek penelitian berada dalam kategori sedang $(98,1 \%)$. Sebanyak $1,4 \%$ relasi orang tua-anak subjek penelitian 
berada pada kategori rendah, dan 0,5\% subjek penelitan berada pada kategori tinggi. Variabel tekanan teman sebaya, Sebagian besar subjek penelitian berada pada kategori sedang $(62,3 \%)$ dan $18,4 \%$ berada pada kategori rendah yang mengindikasikan bahwa tekanan yang diperoleh dari teman sebaya cukup rendah. Sebesar $19,3 \%$ subjek penelitian berada pada kategori tinggi.

\section{Uji asumsi}

Uji normalitas dilakukan dengan Kolmogorov-Smirnov. Kaidah yang digunakan adalah jika $\mathrm{p}>0,05$ maka sebaran data tersebut normal (Ghazali, 2011). Hasil normalitas sebaran data pada variabel menghasilkan nilai $\mathrm{K}-\mathrm{SZ}=1,282 ; \mathrm{p}>0,05$, artinya data dalam penelitian ini terdistribusi normal.

Syarat Model regresi yang baik adalah tidak terjadinya multikoloniearitas atau korelasi antar variabel independen. Hal ini dilihat dari nilai Variance Inflation Factor (VIF) kurang dari 10 dan nilai Tolerance berkisar antara 0,0 - 1 (Ghazali, 2011). Hasil perhitungan nilai Tolerance menunjukkan nilai Tolerance kedua variabel prediktor sebesar 0,999 (nilai Tolerance<1), yang artinya tidak ada korelasi antar variabel independen yang nilainya lebih dari 95\%. Hasil perhitungan nilai VIF juga menunjukkan nilai kedua variabel prediktor sebesar 1,001 (VIF<10) yang mengindikasikan tidak terjadinya multikoliniearitas diantara kedua variabel tersebut.

Pengujian linearitas dilakukan dengan menggunakan analisis varians regresi sederhana. Kaidah yang digunakan dengan melihat $F$ pada lajur linearity $(\mathrm{p}<0,05)$ dan $\mathrm{F}$ pada lajur deviation from linearity $(\mathrm{p}>0,05)$ (Ghazali, 2011). Hasil uji linearitas variabel kecenderungan perilaku pengambilan risiko dan relasi orang tuaanak menunjukkan bahwa hubungan antar variabel telah memenuhi asumsi linear karena F-Deviation From Linearity berada pada rentang tidak signifikan ( $\mathrm{F}=1,457$; $\mathrm{p}>0,05)$. Informasi tambahan menunjukkan bahwa asumsi linearitasnya cukup kuat karena F-Linearity berada pada rentang signifikan $(F=31,550 ; p<0,05)$.

Selanjutnya, hasil uji linearitas antara variabel kecenderungan perilaku pengambilan risiko dan tekanan sebaya juga menunjukkan bahwa hubungan antar variabel telah memenuhi asumsi linear karena nilai F-Deviation From Linearity berada pada rentang signifikan $(\mathrm{F}=1,003$; $\mathrm{p}>0,05)$ dan nilai $\mathrm{F}$-Linearity tidak signifikan $(F=2,284 ; p<0,005)$.

Berdasarkan analisis tersebut menunjukkan tidak adanya penyimpangan yang signifikan, sehingga dapat disimpulkan bahwa kedua variabel prediktor terhadap variabel kriterium menunjukkan hubungan yang linear. Uji hipotesis dilakukan dengan analisis regresi berganda. Hasil analisis regresi menghasilkan nilai $\mathrm{F}=15,823 ; \quad \mathrm{p}=0,000$ $(p<0,05)$ dan nilai $R$ sebesar 0,358 , serta $R$ Square sebasar 0,128. Hasil ini menunjukkan bahwa variabel relasi orang tua-anak dan tekanan teman sebaya secara bersama-sama memengaruhi kecenderungan perilaku pengambilan risiko. Sumbangan efektif yang diberikan kedua variabel prediktor

Tabel 3.

Nilai Koefisien Analisis Regresi Berganda

\begin{tabular}{lcccc}
\hline \multirow{2}{*}{ Variabel } & \multicolumn{3}{c}{ Koefisien } \\
\cline { 2 - 5 } & B & Beta $(\beta)$ & Sig. (p) & Keterangan \\
\hline Relasi orang tua-anak & $-0,422$ & $-0,344$ & 0,001 & Sangat Signifikan \\
\hline Tekanan teman sebaya & $-0,124$ & $-0,115$ & 0,073 & Tidak Signifikan \\
\hline
\end{tabular}


(relasi orang tua-anak dan tekanan teman sebaya) terhadap variabel kriterium (kecenderungan perilaku pengambilan risiko) sebesar 12,8 persen. Berdasarkan analisis tersebut, maka dapat disimpulkan bahwa hipotesis penelitian diterima.

Selain itu, analisis regresi menghasilkan nilai konstanta pada variabel relasi orang tua-anak dan tekanan teman sebaya seperti yang ditunjukkan pada Tabel 3.

Berdasarkan Tabel 3, diketahui bahwa variabel relasi orang tua-anak dapat memprediksi kecenderungan perilaku pengambilan risiko secara signifikan, sementara variabel tekanan teman sebaya tidak. Pada variabel relasi orangtua-anak nilai signifikan $\mathrm{p}$ yaitu $0,001 \quad(\mathrm{p}<0,01)$, sementara pada variabel tekanan teman sebaya nilai signifikan 0,073 ( $p>0,01)$. Dapat disimpulkan bahwa secara independen variabel relasi orang tua dapat memprediksi kecenderungan perilaku pengambilan risiko, namun tidak pada variabel tekanan sebaya terhadap variabel kecenderungan perilaku pengambilan risiko.

\section{Diskusi}

Hasil dari kajian pustaka menunjukkan bahwa relasi orang tua-anak berperan terhadap kecenderungan perilaku pengambilan risiko (Dixson, et al., 2014; Mathijssen, Janssen, Bon-Martens, Oers, Boer, \& Garretsen, 2014; Johnson, 2013; Choo \& Shek, 2013; Tsai, 2013; Klahr, et al., 2011; Stattin \& Kerr, 2000; Jessor, Turbin, Costa, Dong, Zhang, \& Wang 2003). Selain itu, tekanan teman sebaya juga berperan terhadap kecenderungan perilaku pengambilan risiko pada remaja (Gheorghiu, et al., 2015; Derek \& Andrew, 2013; Chein, et al., 2011; Jessor \& Jessor, 2009; Gardner \& Steinberg, 2005). Hasil analisis statistik menunjukkan bahwa relasi orang tua-anak dan tekanan teman sebaya bersama-sama berperan dalam kecenderungan perilaku pengambilan risiko $(F=15,823 ; \quad p<0,05)$. Hal ini mengindikasikan bahwa relasi orang tuaanak dan tekanan teman sebaya memengaruhi dalam kecenderungan perilaku pengambilan risiko.

Hasil temuan berbeda ditunjukkan dari analisis terpisah pada masing-masing variabel prediktor. Hasil analisis regresi secara independen menunjukkan variabel relasi orang tua-anak dapat secara signifikan memprediksi kecenderungan perilaku pengambilan risiko $(\mathrm{F}=28,101$; $\mathrm{p}<0,005)$ dibandingkan dengan tekanan teman sebaya. Variabel tekanan teman sebaya secara independen tidak dapat memprediksi kecenderungan perilaku pengambilan risiko secara signifikan ( $p>0,005)$.

Penelitian oleh Choo dan Shek (2013) menemukan adanya keterkaitan antara tekanan teman sebaya dan relasi orang tuaanak. Relasi orang tua-anak secara signifikan lebih kuat dari pada tekanan teman sebaya dalam memprediksi perilaku minum minuman beralkohol. Tekanan sebaya tidak memberikan pengaruh langsung terhadap perilaku berisiko remaja di Singapore. Begitu juga, berdasarkan model risiko Masten (2001) menemukan bahwa perkembangan remaja adalah hasil interaksi antara faktor pelindung dan faktor risiko, orang tua atau sistem keluarga memperkuat atau melemahkan pengaruh teman sebaya sebagai faktor risiko remaja dalam penggunaan alkohol. Penelitian ini juga didukung dari Barat oleh Crawford dan Novak (2002) yang menemukan bahwa pengaruh kedekatan orang tua-anak menghalangi dalam penggunaan alkohol pada remaja, meskipun anak sering berinteraksi dengan teman sebayanya.

Selain itu, subjek dalam penelitian ini adalah remaja berusia 15-18 tahun atau siswa kelas 10 sampai 12. Menurut penelitian Berndt (dalam Santrock, 2003) menemukan bahwa pengaruh teman sebaya 
khususnya pada perilaku anti sosial remaja memuncak pada kelas delapan dan sembilan. Setelah remaja memasuki kelas sebelas dan dua belas menunjukkan tandatanda berkembangnya gaya pengambilan keputusan yang bebas dari dari pengaruh orang tua dan teman sebaya. Hasil analisis kategorisasi menunjukkan bahwa pada umumnya tekanan teman sebaya subjek penelitian mengarah pada kategori sedang sebesar 62,3\%. Artinya subjek dalam penelitian ini merasa cukup mendapatkan tekanan yang besar dari teman sebayanya. Namun tidak serta merta tekanan teman sebaya tersebut langsung meningkatkan kecenderungan perilaku pengambilan risiko, terlihat dari hasil kategorisasi kecenderungan perilaku pengambilan risiko $75 \%$ mengarah pada kategori rendah. Menurut Clasen dan Brown (1987), remaja dihadapkan dengan tekanan teman sebaya adalah sebelum dan sesudah sekolah menengah. Pada masa sekolah menengah remaja mulai mengalami perubahan fisik secara intelektual, emosional, dan sosial yang lebih luas. Perubahan ini membuat remaja berkomitmen pada tugas menjadi individu yang otonom.

Berbeda dengan tekanan teman sebaya, relasi orang tua-anak secara signifikan dapat berperan terhadap kecenderungan perilaku perilaku pengambilan risiko pada remaja (mereka (DiClemente, Santeli \& Crosby, 2009). Hal ini dapat terlihat pada subjek penelitian bahwa semakin positif relasi orang tua-anak berpengaruh terhadap kecenderungan perilaku pengambilan risiko yang lebih rendah. Penelitian Jessor (2003) menunjukkan bahwa relasi positif antara orang tua dan anak merupakan faktor yang dapat mengurangi perilaku berisiko pada remaja. Misalnya, dukungan dan kasih sayang orang tua berhubungan dengan rendahnya perilaku pengguanaan alkohol, kenakalan, dan penggunaan narkoba.
Dari temuan ini menunjukkan bahwa remaja mempersepsikan relasi dengan orang tua secara positif, artinya remaja merasa cukup mendapatkan dukungan dari orang tua dan mereka dapat menyelesaikan permasalahan dengan baik. Dukungan yang dimaksudkan adalah adanya waktu untuk melakukan berbagai hal bersamasama, seperti melakukan pekerjaan rumah atau kegiatan rekreasi keluarga. Menurut Dixson, et al. (2014) keluarga yang menyisihkan banyak waktu untuk keluarga akan cenderung menciptakan relasi yang positif antar anggota keluarga. Sejalan dengan hal tersebut, Baumrind, Larzele, dan Owens (2010) menyatakan bahwa orang tua yang memberikan kehangatan serta interaksi yang demokratis akan mengembangkan perilaku yang positif.

Selain melakukan kegiatan bersamasama, remaja juga mempersepsikan memiliki keterbukaan dalam komunikasi bersama orang tua. Orang tua mengetahui kegiatan apa saja yang dilakukan anak sehari-hari, dan bersama siapa saja anak melakukan berbagai kegiatan. Keterbukaan komunikasi ini dapat memberikan kesempatan anggota keluarga untuk mengekspresikan perasaannya. Kebebasan berekspresi menumbuhkan perasaan tidak malu untuk mengungkapkan rasa perhatian antar orang tua dan anak. Remaja atau orang tua dapat bebas mengungkapkan perasaan cinta dan sayang dengan penuh kasih tanpa merasa canggung. Saling memberikan pujian dalam keluarga mampu menciptakan kehangatan, hal ini penting untuk menciptakan relasi positif antar keluarga Dixson, et al. (2014).

Begitu juga persepsi remaja terhadap penyelesaian konflik bersama orang tuanya, remaja merasa diberikan kesempatan untuk dapat menjelaskan apa yang mereka alami, sehingga memberikan kenyamanan untuk bagi remaja. Remaja juga cukup merasa ikut andil dalam diskusi mengenai aturan yang dibuat dalam keluarga. Perasaan dihargai 
dan dipertimbangkan pendapatnya membuat remaja berpersepsi positf terhadap hubungannya dengan orang tua (Mathijssen, et al., 2014).

Selain itu, kedua variabel prediktor penelitian ini memberikan sumbangan efektif sebesar tiga belas persen. Berdasarkan kajian pustaka yang telah dilakukan bahwa faktor-faktor yang dapat memengaruhi kecenderungan perilaku pengambilan risiko beragam. Kedua variabel prediktor dalam penelitian ini hanya sebagian kecil dari faktor-faktor lainnya. Menurut Sofronoff, et al., (2004) ada beberapa faktor internal yang dapat memengaruhi perilaku pengambilan risiko, seperti keluarga dengan sejarah penyakit jiwa. Jika seorang anak dilahirkan dari seorang ayah dengan sejarah kriminal, kecenderungan anak untuk melakukan perilako berisiko menjadi lebih besar. Selain itu, kekerasan pada masa kanak-kanak, genetika, penyimpangan seksual juga dapat menjadi faktor dalam pengambilan perilaku berisiko.

\section{Kesimpulan}

Kesimpulan dari penelitian ini adalah bahwa kecenderungan perilaku pengambilan risiko secara bersama-sama dapat diprediksi oleh relasi orang tua-anak dan tekanan teman sebaya. Sumbangan efektif relasi orang tua-anak dan tekanan teman sebaya terhadap kecenderungan perilaku pengambilan sebesar tiga belas persen.

Secara independen, relasi orang tuaanak adalah faktor utama dalam memprediksi kecenderungan perilaku pengambilan risiko. Ketika anak mempersepsikan relasi dengan orang tua secara positif, artinya remaja merasa cukup mendapatkan dukungan dari orang tua dan mereka dapat menyelesaikan permasalahan dengan baik. Sebaliknya, perilaku pengambilan risiko muncul jika remaja menilai negatif relasinya dengan orang tua.
Namun, variabel tekanan teman sebaya pada penelitian ini tidak dapat memprediksi kecenderungan perilaku pengambilan risiko. Ada beberapa hal yang dapat menjadi penyebab tekanan teman sebaya tidak dapat berperan, diantaranya yaitu; adanya keterkaitan antara relasi orang tua-anak dan tekanan teman sebaya; usia subjek penelitian.

\section{Saran}

Saran untuk penelitian selanjutnya adalah perlu mempertimbangkan faktor-faktor lain yang dapat menurunkan kecenderungan perilaku pengambilan risiko, terutama faktor internalnya. Hasil analisis menunjukkan bahwa variabel relasi orang tua-anak dapat berperan secara signifikan dibandingakan tekanan teman sebaya, sehingga disarankan bagi orang tua dan anak untuk menciptakan relasi yang positif agar dapat mengurangi kecenderungan perilaku pengambilan risiko. Relasi positif dapat dikembangkan melalui keterbukaan komunikasi, saling memahami, memberikan perhatian dan pujian, serta mendiskusikan segala sesuatu dengan anak agar anak merasa dihargai. Penyelesaian masalah dengan jalan damai juga penting untuk menghindari relasi negatif antar orang tua dan anak.

\section{Kepustakaan}

Alsa, A. (2014). Pendekatan kualitatif dan kuantitatif serta kombinasinya dalam penelitian psikologi. Cetakan V. Yogyakarta: Pustaka Pelajar.

Badan Koordinasi Keluraga Berencana Nasional (BKKBN). (2011). Kajian profil penduduk remaja (10-24 tahun): Ada apa dengan remaja. Policy Brief Puslitbang Kependudukan. Retrieved from

http://www.depkes.go.id/resources/d
ownload/pusdatin/infodatin/infodatin
\%20reproduksi\%20remaja-ed.pdf
ownload/pusdatin/infodatin/infodatin o20reproduksi\%20remaja-ed.pdf 
Badan Pusat Statistik (BPS). (2012). Survei demografi dan kesehatan Indonesia 2012. Kesehatan Reproduksi remaja. Jakarta: Kementerian Kesehatan Jakarta. Retrieved from http://www.bkkbn.go.id/litbang/pusd u/Hasil\%20Penelitian/SDKI\%202012/L aporan\%20Pendahuluan\%20REMAJA \%20SDKI\%202012.pdf

Badan Pusat Statistik Provinsi D.I. Yogyakarta. (2015). Statistik politik dan keamanan Provinsi Daerah Istimewa Yogyakarta. Yogyakarta: Badan Pusat Statistik.

Baumrind, D., Larzele, R. E., \& Owens, E. B. (2010). Effect of preschool parents' power assertive patterns ang practise on adolescent development. Parenting Science and Practice, 10(3), 157-201.

Bonino, Cattelino, \& Clairano,. (2005). Adolescents and risk, behavior, functions, and protective factors. Italia: Springer.

Burt, S. A., McGue, M., Lacono, W. G., \& Krueger, R. F. (2006). Differential parent-childrelationships and adolescent externalizing symptoms: Cross-lagged analyses within a monozygotic twin differences design. Devevelopmental Psychology, 42, 12891298.

Chein, J., Albert, D., O’Brien, L., Uckert, K., \& Steiberg, L. (2011). Peer increase adolescent risk taking by enhancing activity in the brain's reward circuitry. Journal Development Science, 14(2), F1-F10.

Choo, H., \& Shek, D. (2013). Quality of parent-child relationship, family conflic, peer pressure, and drinking behaviours of adolescents in an Asian context: the case of Singapore. Social Indication Rescue, 110, 1141-1157.

Clasen, D. R., \& Brown, B. B. (1987). Understanding peer pressure in the middle school. Journal of Adolescence, 19(1), 21-23.
Crawford, L. A., \& Novak, K. B. (2002). Parental and peer influences on adolescent drinking: The relative impact of attachment and opportunity. Journal of Child $\mathcal{E}$ Adolescent Substance Abuse, 12(1), 1-26.

Crockett, L. J., Raffaelli, M., \& Shen, Y. L. (2006). Linking self-regulation and risk proneness to risky sexual behavior: Pathways through peer pressure and early substance use. Journal of Research on Adolescence, 16(4), 503-525.

Derek, K., \& Smiler, A. P. (2013). Norms and peer pressure in adolescent boys and girls alcohol use, Substance Use Misuse, 48(5), 371-378.

DiClemente, R. J., Santelli, J. S., \& Crosby, R. A. (2009). Adolescent health. Understanding and preventing risk behaviour. San Franscisco: Jossey-Bass: A Wiley Imprint.

Dixson, M., Bermes, E., \& Fair, S. (2014). An Instrument to investigate expectations about and experiences of the parentchild relationship: The parent-child relationship schema scale. Social Science, 3, 84-114.

Eaton, D. K., Kann, L. \& Kinchen, S. (2006). Youth risk behavior surveillance. Division of Adolescent and School Health, National Center for Chronic Disease Prevention and Health Promotion, 55(5), 1-108.

Faska. (2015, April 5). Pernikahan dini di Jogja meningkat tajam. Pojoksatu. Retrieved from http://pojoksatu.id/news/beritanasional/2015/04/05/pernikahan-dinidi-jogja-meningkat-tajam/

Fisher, L., \& Feldman, S. S. (1998). Familial antecedents of young adulth health risk behavior: A longitudinal study. Journal of Family, 12(1), 68-80.

Gardner, M. \& Steinberg, L. (2005). Peer influence on risk taking, risk preference, and risky decision making in adolescence and adulthood: An 
experimental study. Developmental Psychology, 41(4), 625-635.

Garnefski, N., \& Diekstra, R. F. W. (1996). Perceived social support from family, school, and peers: Relationship with emotional and behavioral problem among adolescents. Journal of the American Academy of Child and Adolescent Psychiatry, 35(12), 16571664.

Gheorghiu, A., Delhomme, P., \& Felonneau, M. L. (2015). Peer pressure and risk taking in young drivers' speeding behavior. Transportation Research Part F, 35, 101-111.

Ghozali, I. (2011). Aplikasi analisis multivariat dengan program IBM SPSS 19, Edisi kelima. Semarang: Universitas Diponegoro.

Gullone, E. \& Moore, S. (2000). Developing adolescents: A reference for professionals. Washington DC: American Psychological Association.

Informasi Kementerian Pemuda dan Olahraga. (2009). Kementerian pemuda dan olahraga. Biro Perencanaan: Sekretariat Kementerian Pemuda dan Olahraga.

Jahun, K. (2011). Patterns of parent-child relationship quality, parent depression and adolescent development outcomes (Disertasi tidak terpublikasi). University of Washington, School of Nursing.

Jessor, R., \& Jessor, T. (2009). Description versus explanation in cross-national research on adolescent. Journal of Adolescent Health, 43(6), 527-528.

Jessor, R., Turbin, M. S., Costa, F. M., Dong, Q., Zhang, H., \& Wang, C. (2003). Adolescent problem behavior in China and the United States: A crossnational study of psychosocial protective factors. Journal of Adolescence Research, 13, 329-360.

Johnson, \& Matthew, D. (2013). Parent-child relationship quality directly and indirectly influences hooking up behaviour reported in young adulthood through alcohol us in adolescence. Arch Sex Behaviour, 42, 1463-1472.

Karriker-Jaffe, K. J., Foshee, V. A., Ennett, S. T., \& Suchindran, C., (2008). The development of aggression during adolescence: Sex differences intrajectories of physical and social aggression among youth in rural areas. Journal Abnormal. Child Psycholology, 36, 1227-1236.

Kementerian Dalam Negeri (Kemendagri). (2014). Kode dan data wilayah administrasi pemerintahan. Jakarta: Ditjen Kependudukan dan Catatan Sipil Kemendagri Per Semester I.

Klahr, A. M., McGue, M., Lacono, W. G., \& Burt, S. A. (2011). The association between parent-child conflict and adolescent conduct problems over time: Results from a longitudinal adoption study. Journal Abnormal Psychology, 120, 46-56.

Masten, A. S. (2001) Resiliensi process in development. American Psichological Association, 56(3), 227-228.

Mathijssen, J. P. J., Janssen, M. M., BonMartens, M., Oers, H. A., Boer, A. D., \& Garretsen, H. F. (2014). Alcohol segment-specific associations between the quality of the parent-child relationship and adolescent alcohol use. Journal of Public Health, 872, 14712458.

Leather, N. C. (2009). Risk-taking behaviour in adolescence: A literature review. Journal of Child Health Care, 13(3), 295304.

Oni, A. A. (2010). Peer group pressure as a determinant of adolescent social adjustment in Nigerian schools. Asian Pasific Journal of Educators and Education, 25, 189-202.

Peacock, A., \& Bruno, R. (2015). Young adults who mix alcohol with energy 
drink: Typology of risk taking behaviour. Addictive Behaviours, 45, 252-258.

Qu, Y., Fuligni, A. J., Galvan, A., \& Telzer, E. H. (2015). Buffering effect of positive parent-child relationships on adolescent risk taking: A longitudinal neuro imaging investigation. Developmental Cognitive Neuroscience, 15, 26-34.

Ritcher. (2010). Risk behavior in adolescence, patterns, determinants, and consequences. Germany: Springer Fachmedien.

Sales, J. M., \& Irwin, C. E., Jr. (2009). Theories of adolescent risk-taking: A biopsychosocial model. In R. DiClemente \& R. Crosby (Eds.), Adolescent health: Understanding and preventing risk behaviors and adverse health outcomes (pp. 31-50). San Francisco, CA: Jossey-Bass.

Santrock, J. W. (2003). Adolescene: Perkembangan remaja. Jakarta: Erlangga.

Savitri, A. R. (2015, Desember 11). Inilah organisasi paling nge-hits di Yogyakarta. Youth Forum. Retrieved from http://www.duniaremaja. jogjaprov.go.id/detilberita/14/1/InilahOrganisasi-Paling-Nge-Hits-diYogyakarta,-YouthForum-DIY

Skaar, N. R. (2009). Development of the adolescent exploratory and health risk behaviour rating scale (Unpublished dissertation). University of Minnesota, United Stated.

Sofronoff, Dalgliesh, \& Kosky. (2004). Out of options, a cognitive model of adolescent suicide and risk-taking. USA: Cambridge University Press.

Stattin, H., \& Kerr, M. (2000). Parental monitoring: A reinterpretation. Child Developmental, 71, 1072-1085.

Survei Demografi dan Kesehatan Indonesia. (2013). Kesehatan reproduksi remaja. Badan Pusat Statistik. Jakarta: Indonesia.
Tsai, K. M. (2013). Continuity and discontinuity in perceptions of family relationship from adolescence to young adulthood. Journal of Child Development, 84(2), 471-484.

Turley, R. N. L., Desmond, M., \& Bruch, S. K. (2010). Unanticipated educational consequences of a positive parentchild relationship. Journal of Marriage and Family, 72(5), 1377-1390. 